\title{
The correlation of the low birth weight with stunting incident on child aged 6-59 months in Lampung-Indonesia
}

\author{
Yesi Nurmalasari ${ }^{1}$, Ringgo Alfarisi ${ }^{2}$, Syawalia Kartika ${ }^{3}$ \\ 1,2,3 Faculty of Medicine University of Malahayati, Bandar Lampung-Indonesia. \\ E-mail: yesinurmalasari.dr@gmail.com
}

\begin{abstract}
Background: Stunting or short was failed condition to grow of the baby (0-11 months old) and toodler (12-59 months old) impacted of the cronic malnutrition especially in the first 1.000 days of life its effecting the children to be too short. LBW is a factor that most dominant risk against stunting on child.

Purpose : This research was to know the Correlation between history of low body weight of birth with the genesis stunting of the toodler aged 6-59 months in Mataram llir Village Seputih Surabaya Central Lampung 2019.

Methods: This type of research is analysis observation with cross sectional design with purposive sampling as the sampling technique and Chi Square test as the bivariate analysis.

Results: The results of the analysis showed that the frequency distribution of children with a history of LBW was $85(35 \%)$, and the proportion of respondents with a history of normal weight birth was $152(64.1 \%)$. While the frequency of the incidence of infants with normal height was $141(59.5 \%)$, and the frequency of genesis stunting was $96(40.5 \%)$. The results showed that the p-value was 0.005 and OR was $2.282(95 \% \mathrm{Cl}: 1.29-3.8)$.

Conclusion: There was a significant relationship between history of LBW and genesis stunting.
\end{abstract}

\section{Keywords: Low Body Weight; Birth history; Stunting}

\section{INTRODUCTION}

Stunting is a condition of failure to thrive in infants (0-11 months) and toddler (12-59 months) by the result of chronic malnutrition especially in the first 1000 days of life so that children are too short for the age. The malnutritions since it was still in the womb and the beginning of life but it appears when the child is 2 years old (Persatuan Ahli Gizi Indonesia, 2018).

The global in 2017 many as $22,2 \%$ or one out of four children aged 0-5 years in the world have stunting. The highest prevalence of stunting was $35 \%$ by Southeast Asia, and for the second highest by East Africa and South Africa was $34,1 \%$ and third highest by West Africa and Central Africa was 33,7\% (UNICEF, 2010; Akombi, Agho, Hall, Merom, Astell-Burt, \& Renzaho, 2017; Lestari , Rezeki, Siregar \& Manggabarani, 2018).

Lampung have ranking of the high stunting prevalence in Indonesia is 24 of 34 in the amount of $27,3 \%$ for stunted and severly stunted. The subdistrict of lampung for the entering 100 intervention stunting locations in the year of 2018 is South of
Lampung, East of Lampung and Central of Lampung (Persatuan Ahli Gizi Indonesia, 2018).

The low birth weigh have the big impact for the growt and development of for the child. The low birth weight will be at high risk for morbidity, death, infectious disease, lack of weight and stunting which begins the neonatus period until childhood. The high rate of low birth weight is thought to be the caused of the high incident of stunting and also became the dominant factor in the incident of stunting (Nadiyah, Briawan, \& Martianto, 2014; Nasution, Nurdiati, \& Huriyati, 2014).

National prevalence of the low birth in the amount of $11,1 \%$. The high prevalence of low birth weight have the factor of stunting because from the research $9,5 \%$ the baby have the low birth weight and $22 \%$ at the point of result stunting incident by Ernawati 2014 researce (Sari, Mambang, Putri, Haryono, Lestari, \& Sari, 2017).

\section{RESEARCH METHODS}

The study was observasional analitytic, with cross sectional design. This research location was in Mataram llir Village Seputih Surabaya Sub- 
The correlation of the low birth weight with stunting incident on child aged 6-59 months in Lampung-Indonesia

District In Central of Lampung on February 2019. The sample were 237 samples and taken with purposive random sampling. The analysis used statistical test with Chi-square for significant for the variables.

\section{RESEARCH RESULTS}

Table 1. Characteristics of Toddlers by Gender $\mathrm{N}=237$

\begin{tabular}{ccc}
\hline Gender & Frequency (f) & Percentage (\%) \\
\hline Girl & 129 & 54,5 \\
Boy & 108 & 45,5 \\
Total & 237 & 100 \\
\hline
\end{tabular}

Based on table 2 above it is known that toddlers by gender are mostly the girl in the amount of $129(54,5 \%)$ and the boy are 108 (45,5\%).

Table 2. Characteristics of Toddlers by Age $\mathrm{N}=237$

\begin{tabular}{ccc}
\hline Age & Frequency (f) & Percentage (\%) \\
\hline 6-12 Months & 21 & 8,9 \\
13-24 Months & 58 & 24,5 \\
25-36 Months & 69 & 29,1 \\
37-48 Months & 41 & 17,3 \\
45-59 Months & 48 & 20,3 \\
Total & $\mathbf{2 3 7}$ & $\mathbf{1 0 0}$ \\
\hline
\end{tabular}

Based on table 1 above it is known that toddlers by age of the tallest from this research is $25-36$ month in the amount of $69(29,1 \%)$. The next most toddlers are 13-24 months of age in the amount of $58(24,5 \%)$, the toddlers by age $49-59$ months in the amount of $48(20,3 \%)$, the toddlers by age $37-48$ months in the amount of $41(17,3 \%)$ and then by age in the amount of $6-12$ months in the amount of $21(8,9 \%)$.

Table 3. Frequency Distribution by The Low Birth Weight $\mathrm{N}=237$

\begin{tabular}{ccc}
\hline The Low Birth Weight & Frequency (f) & Percentage (\%) \\
\hline Normal & 152 & $64,1 \%$ \\
The Low Birth Weight & 85 & $35,9 \%$ \\
Total & $\mathbf{2 3 7}$ & $\mathbf{1 0 0 \%}$ \\
\hline
\end{tabular}

Based on table 3 above it is known that toddlers in the normal in the amount of $152(64,1 \%)$, and the low birth weight in the amount of $85(35,9 \%)$. 
The correlation of the low birth weight with stunting incident on child aged 6-59 months in Lampung-Indonesia

Table 4. Frequency Distribution by The stunting incident $\mathrm{N}=237$

\begin{tabular}{ccc}
\hline Stunting Incident & Frequency (f) & Percentage (\%) \\
\hline Normal $(\geq-2 S D)$ & 141 & $59,5 \%$ \\
Stunting(<-2SD) & 96 & $40,5 \%$ \\
Total & 237 & $100 \%$ \\
\hline
\end{tabular}

Based on table 4 above it is known that toddlers in normal ( $\geq-2 S D)$ in the amount of $141(59,5 \%)$, and stunting incident in the amount of $96(40,5 \%)$.

Tabel 5. The Correlation of The Low Birth Weight with Stunting Incident N=237

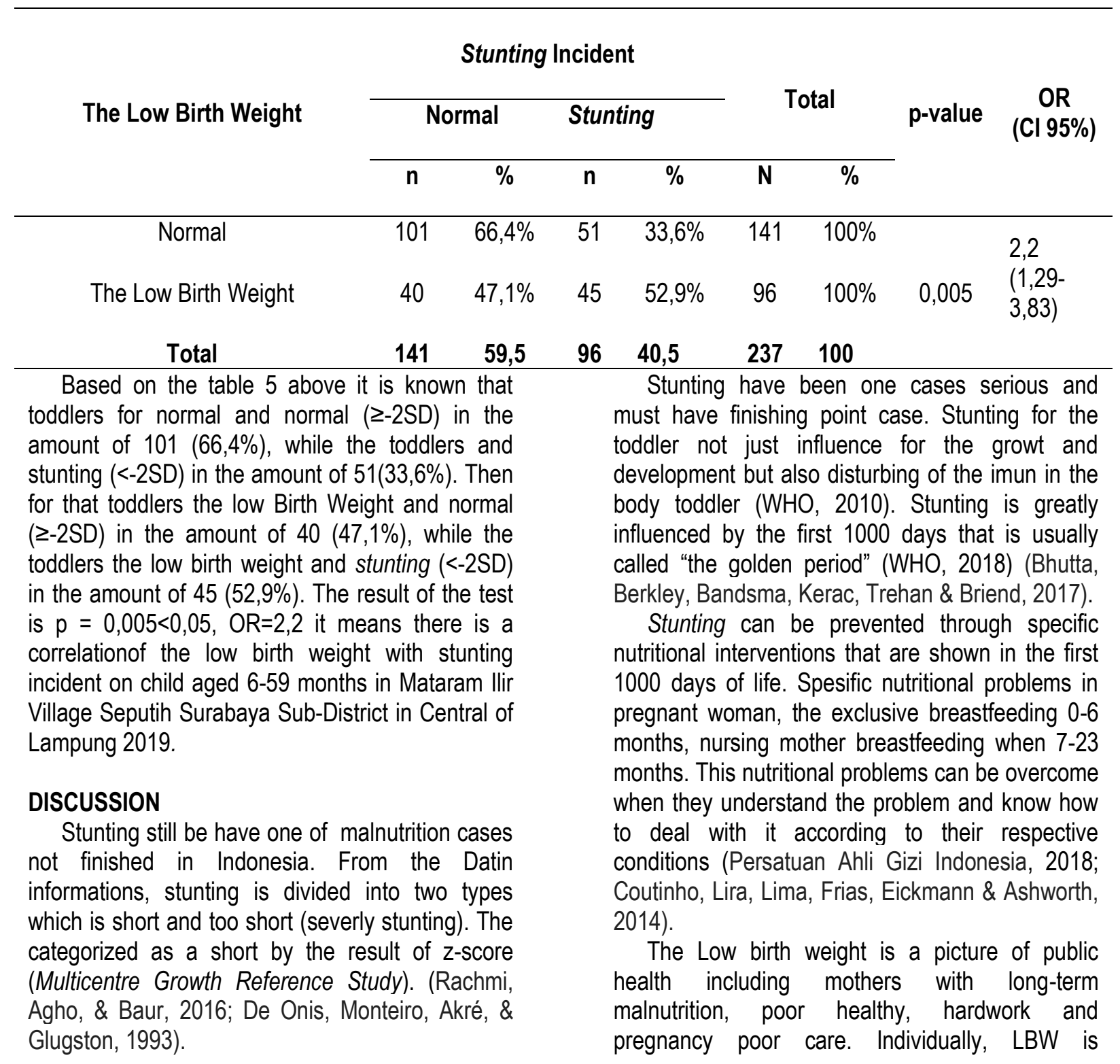

Yesi Nurmalasari', Ringgo Alfarisi ${ }^{2}$, Syawalia Kartika ${ }^{3}$ Faculty of Medicine University of Malahayati, Bandar Lampung-Indonesia. E-mail: yesinurmalasari.dr@gmail.com 
The correlation of the low birth weight with stunting incident on child aged 6-59 months in Lampung-Indonesia

important predictor in the health and survival of newborns and is associated with high risk in children (UNICEF, 2010; Schellong, Schulz, Harder \& Plagemann, 2012). Birth weight in general is close related to the growth of long-term development. Thus, the subsequent impact of LBW can be in the form of growth failure. Someone born with LBW will find it difficult to catch up with the initial growth. Growth that lags behind normally will cause the child to become stunting (Oktarina, \& Sudiarti, 2013).

The toddler LBW is more at risk of becoming stunting because LBW toddlers have a higher susceptibility ti infectious diseases, such as diarrhea and lower respiratory tract infections and increased risk of complications including sleep apnea jaundice, anemia, chronic lung disorders, fatigue, and loss of appetite compared to children with normal birth weight resulting in not optimal physical growth (Rahman, Howlader, Masud, \& Rahman, 2016; Arrieta, Stiemsma, Amenyogbe, Brown \& Finlay, 2014).

Chronic malnutrition when pregnant woman are caused by a lack of insufficient food intake related to low birth weight babies. This shows the effect that is important for subsequent health so that LBWs are very likely to become short toddlers that the incidence of LBW is caused by nutrition during pregnancy so that the risk of growth in infants under five causes a problem with growth problems is stunting (Lamid, 2015).

The result of this study are in line with the research conducted by Nasution et al in 2014 in the title Low Birth Weight with the efficacy of stunting in children aged 6-24 months who stated that there was a relations between LBW and the incidence of stunting in children aged 6-24 months is 5,6 times more risk for experience stunting in children with a history of low birth weight than children born with normal weight. The study was also in line with the research of (Supriyanto, Paramashanti, \& Astiti, 2018). entitled LBW related to the incidence of stunting in children aged 6-23 months in Yogyakarta who stated that LBW children had a significant relationship with the incidence of stunting ( $p$-value $<0,000)$ in other words children born whit a chance of 6,16 times more likely to experience stunting than children who have a normal birth weight. (Aryastami,
Shankar, Kusumawardani, Besral, Jahari \& Achadi, 2017; Abuya, Ciera \& Kimani-Murage, 2012; Raj, Saggurti, Winter, Labonte, Decker, Balaia \& Silverman 2010; Nandi, Bhalotra, Deolalikar \& Laxminarayan, 2017).

\section{CONCLUSION}

Frequency Distribution the low birth weigh in the amount of $85(35,9 \%)$, the stunting incident is most of normal in the amount of 96 (40,5\%). There is a correlation of the low birth weight with stunting incidentnilai $p$-value $0,005(0,000<0,05)$.

\section{REFERECES}

Abuya, B. A., Ciera, J., \& Kimani-Murage, E. (2012). Effect of mother's education on child's nutritional status in the slums of Nairobi. BMC pediatrics, 12(1), 80.

Akombi, B. J., Agho, K. E., Hall, J. J., Merom, D., AstellBurt, T., \& Renzaho, A. M. (2017). Stunting and severe stunting among children under-5 years in Nigeria: A multilevel analysis. BMC pediatrics, 17(1), 15.

Arrieta, M. C., Stiemsma, L. T., Amenyogbe, N., Brown, E. M., \& Finlay, B. (2014). The intestinal microbiome in early life: health and disease. Frontiers in immunology, 5, 427.

Aryastami, N. K., Shankar, A., Kusumawardani, N., Besral, B., Jahari, A. B., \& Achadi, E. (2017). Low birth weight was the most dominant predictor associated with stunting among children aged 12-23 months in Indonesia. BMC Nutrition, 3(1), 16.

Bhutta, Z. A., Berkley, J. A., Bandsma, R. H., Kerac, M., Trehan, I., \& Briend, A. (2017). Severe childhood malnutrition. Nature reviews Disease primers, 3, 17067.

Yesi Nurmalasari', Ringgo Alfarisi', Syawalia Kartika ${ }^{3}$ Faculty of Medicine University of Malahayati, Bandar Lampung-Indonesia. E-mail: yesinurmalasari.dr@gmail.com 
The correlation of the low birth weight with stunting incident on child aged 6-59 months in Lampung-Indonesia

Coutinho, S. B., Lira, P. I., Lima, M. C., Frias, P. G., Eickmann, S. H., \& Ashworth, A. (2014). Promotion of exclusive breast-feeding at scale within routine health services: impact of breastfeeding counselling training for community health workers in Recife, Brazil. Public health nutrition, 17(4), 948-955.

De Onis, M., Monteiro, C., Akré, J., \& Glugston, G. (1993). The worldwide magnitude of proteinenergy malnutrition: an overview from the WHO Global Database on Child Growth. Bulletin of the World health Organization, 71(6), 703.

Lestari, W., Rezeki, S. H. I., Siregar, D. M., \& Manggabarani, S. (2018). Faktor Yang Berhubungan dengan Kejadian Stunting pada Anak Sekolah Dasar Negeri 014610 Sei Renggas Kecamatan Kisaran Barat Kabupaten Asahan. Jurnal Dunia Gizi, 1(1), 59-64.

Nadiyah, N., Briawan, D., \& Martianto, D. (2014). Faktor Risiko Stunting Pada Anak Usia 0-23 Bulan Di Provinsi Bali, Jawa Barat, Dan Nusa Tenggara Timur. Jurnal Gizi dan Pangan, 9(2).

Nandi, A., Bhalotra, S., Deolalikar, A. B., \& Laxminarayan, R. (2017). The human capital and productivity benefits of early childhood nutritional interventions. In Child and Adolescent Health and Development. 3rd edition. The International Bank for Reconstruction and Development/The World Bank.

Nasution, D., Nurdiati, D. S., \& Huriyati, E. (2014). Berat badan lahir rendah (low birth weight) dengan kejadian stunting pada anak usia 6-24 bulan. jurnal gizi klinik Indonesia, 11(1), 31-37.

Persatuan Ahli Gizi Indonesia. (2018). Stop Stunting Dengan Konseling Gizi. Penebar PLUS+.
Rachmi, C. N., Agho, K. E., Li, M., \& Baur, L. A. (2016). Stunting, underweight and overweight in children aged 2.0-4.9 years in Indonesia: prevalence trends and associated risk factors. PloS one, 11(5), e0154756.

Raj, A., Saggurti, N., Winter, M., Labonte, A., Decker, M. R., Balaiah, D., \& Silverman, J. G. (2010). The effect of maternal child marriage on morbidity and mortality of children under 5 in India: cross sectional study of a nationally representative sample. Bmj, 340, b4258.

Sari, A., Mambang, M., Putri, K. S. C. E., Haryono, I. A., Lestari, Y. P., \& Sari, M. Y. (2017, December). Factors Affecting The Stunting Case: A Retrospective Study On Children In Banjarmasin. In 2nd Sari Mulia International Conference on Health and Sciences 2017 (SMICHS 2017)-One Health to Address the Problem of Tropical Infectious Diseases in Indonesia. Atlantis Press.

Schellong, K., Schulz, S., Harder, T., \& Plagemann, A. (2012). Birth weight and longterm overweight risk: systematic review and a meta-analysis including 643,902 persons from 66 studies and 26 countries globally. PloS one, $7(10)$, e47776.

Supriyanto, Y., Paramashanti, B. A., \& Astiti, D. (2018). Berat badan lahir rendah berhubungan dengan kejadian stunting pada anak usia 6-23 bulan. Jurnal Gizi dan Dietetik Indonesia (Indonesian Journal of Nutrition and Dietetics), 5(1), 23-30.

UNICEF. (2010) Penuntun Hidup Sehat. Jakarta: Pusat Promosi Kesehatan - Kementerian Kesehatan Rl. Diakses dari http://www.depkes.go.id/resources/download/pr omosi-kesehatan/buku-penuntun-hidupsehat.pdf 